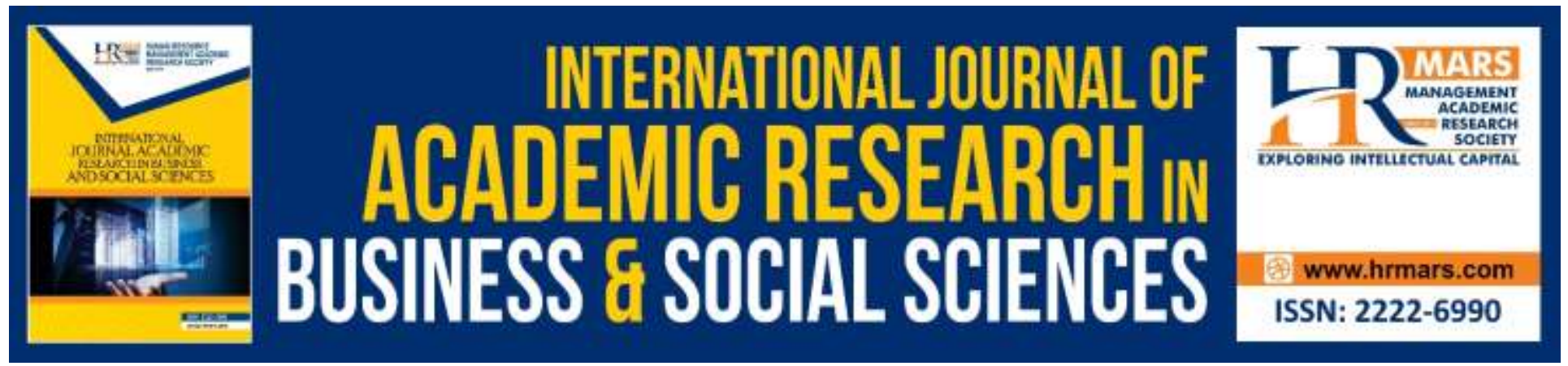

\title{
Prebendalism and Budget Authorization in the Nigerian Legislature
}

\begin{abstract}
Amaechi, Obinna Charles, Amadi, Cletus Okechukwu, Nnaji, Sylvester Ejike
\end{abstract}

To Link this Article: http://dx.doi.org/10.6007/IJARBSS/v8-i7/4324

DOI: $10.6007 /$ IJARBSS/v8-i7/4324

Received: 02 June 2018, Revised: 19 June 2018, Accepted: 26 June 2018

Published Online: 19 July 2018

In-Text Citation: (Amaechi, Amadi, \& Nnaji, 2018)

To Cite this Article: Amaechi, O. C., Amadi, C. O., \& Nnaji, S. E. (2018). Prebendalism And Budget Authorization In The Nigerian Legislature. International Journal Of Academic Research In Business And Social Sciences, 8(7), 58-71.

Copyright: (C) 2018 The Author(s)

Published by Human Resource Management Academic Research Society (www.hrmars.com)

This article is published under the Creative Commons Attribution (CC BY 4.0) license. Anyone may reproduce, distribute, translate and create derivative works of this article (for both commercial and non-commercial purposes), subject to full attribution to the original publication and authors. The full terms of this license may be seen

at: http://creativecommons.org/licences/by/4.0/legalcode

Vol. 8, No. 7, July 2018, Pg. $58-71$

http://hrmars.com/index.php/pages/detail/IJARBSS

JOURNAL HOMEPAGE

Full Terms \& Conditions of access and use can be found at http://hrmars.com/index.php/pages/detail/publication-ethics 


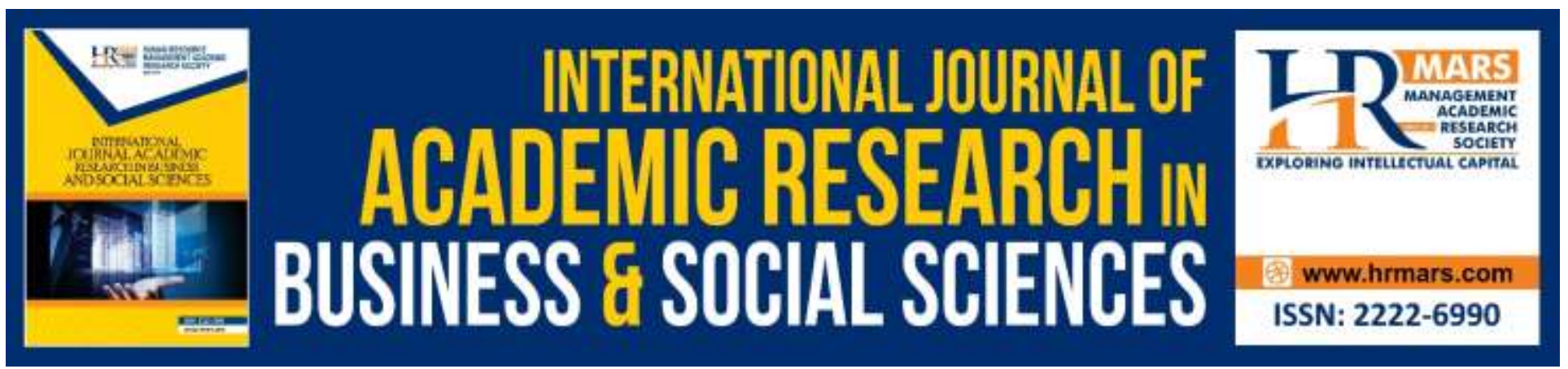

\title{
Prebendalism and Budget Authorization in the Nigerian Legislature
}

\author{
AMAECHI, Obinna Charles
}

PhD Candidate, Department of Political Science, University of Nigeria, Nsukka Email:amaechioc@yahoo.com

AMADI, Cletus Okechukwu, Ph.D

Department of Political Science, Enugu State University of Science and Technology, Enugu

Email: amadicletus07@gmail.com

\section{NNAJI, Sylvester Ejike}

Department of Political Science and International Relation, Godfrey Okoye University

Email: Ejikennaji771@yahoo.com

\begin{abstract}
In recent times, the process by which the parliament approves budget estimate from the chief executive has being hijacked by self-serving elements in the National Assembly at the detriment of the masses. Reports abound on how the Nigerian parliament made themselves the highest paid law makers in the whole world, cases of law makers demanding bribes from ministries in which they have oversight functions on have been reported severally. This paper attempts to discuss the effects of the prebendalists on budget authorization, and the means through which they prebendalize during the process of budget authorization in the Nigerian legislature. The paper identified over bloating of budget, neglect in their oversight functions, delay of budget by anti government forces in the parliament, etc. as the major effects. The paper also revealed that illegal allowances, award/implementation of constituency projects, and padding of budgets through government agencies such as Small and Medium Enterprises Development Agency of Nigeria (SMEDAN), Nigerian Directorate of Employment (NDE), Ogun-Osun River Basin Development Agency (OORBDA), Lower Niger River Basin Development Agency (LNRBDA) and other river basin agencies serve as conduit pipes through which lawmakers prebendalize. Data collection was through secondary sources while content analysis was adopted as a method of analysis. The paper was interrogated using Prebendalism as a framework of analysis. It was recommended that the House of Senate be scrapped and only the House of Representatives retained to save cost. It was also recommended that the Nigerian masses should organize a peaceful protest to the National assembly to demand for an end to self - representation, and finally, a convocation of Sovereign
\end{abstract}


INTERNATIONAL JOURNAL OF ACADEMIC RESEARCH IN BUSINESS AND SOCIAL SCIENCES

Vol. 8, No. 7, July 2018, E-ISSN: 2222-6990 @ 2018 HRMARS

National Conference was suggested to enable Nigerians establish an independent guideline for selecting credible people into leadership positions.

Keywords: Budget Authorization, Budget Estimate, Nigerian Legislature, Prebendalism.

\section{Introduction}

Modern form of democracy has grown with several variants from presidential to parliamentary or cabinet systems, with each recognizing the right of the people to elect their representatives in government (Osagie, 2017). A key feature of a democratic government is the doctrine of separation of powers. It is important for the smooth running of government that the persons entrusted with state power in any of the three organs, executive, judiciary and legislature, shall not be permitted to encroach upon the powers confided in one person or a group of persons, as a result therefore, governmental powers have been divided and rested in three different organs. Each of these organs should be independent of the others. No organ should perform the functions belonging to the other (Montesquieu, 1748 in Osagie, 2017). This principle is the major ingredient of democracy which guarantees that the executive arm of government neither control the affairs of the legislature nor the judiciary. The doctrine of the separation of powers implies that there should be three separate organs of government with their separate sets of functions and powers. The presidential system of government being practiced in Nigeria makes provision for separation of powers, apportioning disparate powers and duties to the executive, legislative and judicial arms of government (Nwagwu, 2014). The legislature has the power of oversight over the execution and administration of laws by the executive including the yearly national budget.

The Nigerian budgetary process under the military has a history of executive dominance, very poor public expenditure management and lack of accountability and transparency. This provides the background to the emerged democratic budgeting process and ultimately explains the various challenges being faced by the legislature and the public in the process of scrutinizing the national budget (Chikeleze, 2002). Since the advent of our evolving democratic experience, the expectations are that a new culture of democracy will be institutionalized to ensure that the allocation of public resources is in line with the needs of the electorate. This has to be achieved by the robust and comprehensive process in which the budget is expected to undergo in the legislature where the people's representatives are expected to make an input to reflect the diverse aspirations of the geographical diversities of the country. However, the quality \& character of the honourable members of the Nigerian parliament has in no small measure affected the authorization of budget leading to the adverse socio - economic conditions being witnessed today. These elements who struggle for elective positions in order to realize their personal agenda of self-enrichment are therefore regarded as prebendalists. They compete for elective positions because of their individual economic interests. At a different fora, top government functionaries including some members of the legislature has come hard against the legislature in Nigeria. A former member of the House of Representatives and former governor of Benue State, Gabriel Suswam had once described members of the National Assembly as uneducated, imamature, and that out of 360 persons, only 20 were useful (Ajani, Agande, \& Binniyat, 2010). One of the present serving governors, Mallam Nasir El-Rafai, had alleged that two principal Officers of the National Assembly - Senator Ibrahim Mantu, the Deputy Senate President and Senator Jonathan Zwingina, the Deputy Senate Leader demanded the sum of N54 million from him to be cleared as a ministerial nominee. There was also a case of Honourable Haruna Yerima and his colleagues over the GSM bribery scandal. Yerima had alleged that - members of the house of assembly demand money from ministries to pass their budgets 
(Mamza, 2005). More so, the incident that led to the impeachment of the then Senate President, Senator Adolphus Wabara in 2005 and the sack of the then Honourable Minister of Education, Professor Fabian Osuji serves as an 'eye opener' on the level of integrity of the members of the Nigerian Parliament and their actions in relation to budgetary issues.

Professor Fabian Osuji and other top members of the ministry of education gave a bribe of N80 million to the then Senate President and other law makers including Senator John Azuta Mbata, Chairman Senate Committee on Appropriation; Senator Ibrahim Abdulazeez, Chairman, Senate Committee on Education; Senator (Dr) Chris Adighije; Senator Badamasi Maccido; Senator Emmanuel Okpede; Honourable (Dr) Shehu Matazu who was the Chairman House Committee on Education; Honourable Gabriel Suswan, and Honourable Osita Izunaso. In recent times, report abound on how agencies of government in which the National Assembly have oversight function on send the law makers on training in overseas, a situation that could mar the moral efficacy of the honourable members to creditably discharge their supervisory duties.

From the above incidences, the personalities of the Nigerian legislatures have been unveiled. However, the effect of these shameful dispositions and the conduit pipes through which these lawmakers siphon our collective resources during the process of budget authorization is the concern of this paper.

\section{Theoretical Conceptualizations}

\section{The Budget}

The budget is a central policy document of government, showing how it will prioritise and achieve its annual and multi-annual objectives. Apart from financing new and existing programmes, the budget is the primary instrument for implementing fiscal policy, and thereby influencing the economy as a whole (OECD, 2014). It is an annual financial statement of the country that estimates the anticipated government revenues and government expenditures for the ensuing financial year. The Chartered Institute of Management Accountants defined Budget as a financial and or quantitative interpretation, prior to a defined period of time, of a policy to be pursued for that period to attain a given objective (Nwabueze, 1999).

\section{The Process of Budget Authorization in the Nigerian Legislature}

Chikeleze (2002) is of the view that budget authorization/approval takes place in the legislature. Therefore, budget authorization is the process by which the parliament approves the budget estimates for onward transmission to the chief executive for an 'assent'.

Chikeleze (2002) submits that after the articulation of the proposals from various ministries, agencies and departments, the Chief Executive presents the budget to the National Assembly for approval in line with the requirements of the Constitution. Subsequently the House Committee on Public Finance reviews the submissions in consideration of the available resources, competing demands, public interest, prudence and other indices meant to ensure the satisfaction of priority needs of the nation. The process of approval includes Committee discussions, House consideration of the Committee reports, and subsequently Adoption. The bill is then sent for Presidential assent which must be given or refused within 30days. If given, it will be finally signed into law as Appropriation Act. Alternatively a two third majority vote of the two houses (Senate and House of Representatives) together may pass the bill into law without a Presidential assent if the president fails to give his assent within a specified period (Chikeleze, 2002). 
INTERNATIONAL JOURNAL OF ACADEMIC RESEARCH IN BUSINESS AND SOCIAL SCIENCES

Vol. 8, No. 7, July 2018, E-ISSN: 2222-6990 @ 2018 HRMARS

\section{Reasons for Budget Authorization by the Legislature}

According to Chikeleze (2002), below are the major reasons why budget estimates should be presented to the legislature for approval:

i) It provides an opportunity for the public (through the assembly) to give a formal approval to the policies of the government and approve the release of funds for the pursuit of those policies.

ii) It ensures that a balanced view is taken in the conduct of government affairs by preventing lopsidedness in the allocation of resources.

iii) It enables the public (through the assembly) to offer an alternative approaches to the pursuit of government goals which the executive may not have considered.

iv) The National Assembly helps to ensure that budget proposals are balanced and congruent with national objectives as well as agreeable with the prevailing circumstances of the nation during the budget period.

\section{The Effects of Prebendalism on Budget Authorization in the Legislature Overbloating of the Subject}

Budget padding is not only fraudulent, but a destructive crime against the future of the people (Temionu, 2016). The over bloating of the national budget for selfish reasons otherwise known as 'padding' is a yearly ritual for the lawmakers who see law making as an avenue for self-enrichment. These lawmakers saddled with the responsibility to authorize budget estimate sent by the Chief Executive, see the responsibility as an opportunity to add fat salaries and allowances for themselves. A look at the 2016 budget drama revealed the level of monumental corruption that has eaten deep into the fabric of our lawmakers' conscience. The Chairman of the House on Appropriation, Abdulmumin Jibrin (APC, Kano State) was accused of padding the 2016 budget estimate in excess of N4 billion for his constituency projects. The lawmaker who did not take it lightly decided to expose the shady deals being perpetrated by the leadership of the House. He in turn accused the House Leadership of corruption. He maintained that not only that there is corruption in the House of Representatives, but 'institutional corruption' which he is ever ready to prove. He accused the Speaker of the House of Representatives, Yakubu Dogara, Deputy Speaker Yusuf Lasun, Chief Whip Alhassan Ado Doguwa, and Minority Leader Leo Ogor of attempting to add N40 billion into the 2016 budget (Agbajileke, 2017; Temionu, 2016). He reasoned that the allegation by former President, Olusegun Obasanjo that 'the National Assembly was populated by corrupt elements' could not be dismissed. As a result of these, Temionu (2016) sees padding as a yearly ritual and a dangerous propeller that has been pulling down our economy, which has refused to be disengaged in order to enable the vessel of Nigeria's economy and nation-building to move ahead.

In another scenario, the Nigeria's National Assembly annual budget was made public after many years of keeping it secret. From the breakdown, the National Assembly's 2017 budget was pegged at \$393million - a \$31 million increase from 2016. The documents showed that Nigerian Senators earned $\$ 55,000$ a year in salary, while the House of Representatives members earned $\$ 42,000$. Aside this, there is also generous allowances. When put together, each lawmaker costs taxpayers about \$540,000 to maintain in 2017 (Kazeem, 2017). Kazeem (2017) further reasoned that while state governments across the country struggle to pay workers' salaries given the economic downturn over the past months, the lawmakers do not experience any delays getting paid. This is because, the national assembly's funds are part of a statutory transfer category which the government is required to grant high priority. Kazeem (2017) concluded that the lawmakers' lavish 
INTERNATIONAL JOURNAL OF ACADEMIC RESEARCH IN BUSINESS AND SOCIAL SCIENCES Vol. 8, No. 7, July 2018, E-ISSN: 2222-6990 @ 2018 HRMARS

pay is almost 10,000 times more than the national minimum wage and is more than 200 times Nigeria's GDP per capita (Kazeem, 2017).

In an interview with Senator Shehu Sani, he disclosed that each Senator takes home about N13.3 million monthly as 'running cost' and another N700,000 in wages. The implication of this according to Itaghene (2018) and Animasaun (2018) is that each senator takes home about N14 million every month, aside their salaries. For 109 senators, this comes to about $\mathrm{N} 1.529$ billion every month translating to about N18.312 billion every year. This means that by the end of a four year circle it would have amounted to N73.248 billion.

Itaghene (2018) pointed that in the 2017 federal budget, the National Assembly got a total of N125 billion. This was said to be a reduction from N150 billion of the previous year. The budget was broken down to show that National Assembly Management got N6,714,696,986 for personnel cost, $\mathrm{N} 6,193,052,825$ for overhead cost and N2,011,315,202 for capital vote. This amounted to a total of $\mathrm{N} 14,919,065,013$. Senate itself got a total of N31,398,765,886 broken down to $\mathrm{N} 1,856,510,517$ for personnel cost, $\mathrm{N} 25,111,332,147$ for overhead cost and $\mathrm{N4}, 430,923,222$ for capital vote. On the other hand, the House of Representatives received N4,923,743,127 for personnel cost, $\mathrm{N} 39,635,756,179$ for overhead cost and N4,493,244,677 for capital vote amounting to a total of $\mathrm{N} 49,052,743,983$. The breakdown further showed that the National Assembly Service Commission received N961,257,912 for personnel cost, N1,144,662,999 for overhead cost and N309,791,962 for capital cost amounting to $\mathrm{N2}, 415,712,873$ in total. For legislative aides, a total of N9,602,095,928 was approved with a breakdown of N8,917,127,214 for personnel cost, N534,968,714 for overhead cost and N150,000,000 for capital cost. While the Public Account Committee PAC of the Senate got a total of N118,970,215 from the 2017 budget, the Public Account Committee of the House of Representatives received N142,764,258. Also from that budget, 'General Services' got a total of $\mathrm{N} 12,584,672,072$ with $\mathrm{N} 11,767,743,268$ going for overhead and N816,928,811 going in for Capital

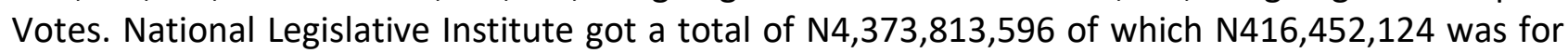
personnel cost, N1,229,369,283 was for overhead and N2,727,992,189 was for capital expenditure. Service Wide Vote of the National Assembly was put at N391,396,169. From the above figures, a total budget of $\mathrm{N} 125,000,000,000$ was written off.

However, Itaghene (2018) argued that the impact of N31,398,765,886 which is a fraction of the share of the Senate will make more meaning when applied against tangibles. For example, he pointed at the opinion of experts who believe that aside the cost of land, N2 million can construct a primary health center that comprises of a general sitting area, one consulting room and a dispensing room. With this projection, it means that a fraction of the Senators' 'running cost' and wages, could build 774 primary health centres for each of the 774 local government areas. That would amount to a total of about N1,548,000,000 in each fiscal year. In order words, in a four year circle, each local government in Nigeria would have had four primary health centers PHCs built out of a fraction of the 'running cost' and salary of Nigerian Senators. Itaghene (2018) maintained that a similar analysis on the running cost and wages of the House of Representatives members would make up for equipment and staffing of such primary health centres. If on the other hand provision of borehole for each of the $\mathbf{7 7 4}$ local government areas is to be funded from the running cost of Senators, the breakdown would, show that at N1 million per borehole, each of the 774 local governments would have gotten four bore holes sunk out of the Senators' running cost', and they will still have enough money left to spend. N1 million per borehole per local government translates to N774 million per year. In four years it would come to N3,096,000,000 and the Senators would still have about N14.9billion to share annually (Itaghene, 2018). Itaghene (2018) regrets that as at present, many 
INTERNATIONAL JOURNAL OF ACADEMIC RESEARCH IN BUSINESS AND SOCIAL SCIENCES Vol. 8, No. 7, July 2018, E-ISSN: 2222-6990 @ 2018 HRMARS

legislatures, who condemned the huge pay made to the Senators and used same as a campaign issue, have remained silent over the issue. They neither criticized what is paid to them nor do they frown at it. None of them have demanded for an end to what they are being paid, against existential realities of life in Nigeria. None has so far brought a private members bill seeking for a law to reduce what senators are being paid. This according to him, indicates that there is so much hypocrisy about fixing wage differentials in Nigeria.

Based on the above view, Harts (2015) asserts that Nigerian legislators earn much more than British Prime minister and more than twice as much as Muhammadu Buhari is supposed to receive as the President of Nigeria. Muhammadu Buhari's annual presidential salary is N14,058,80 which is approximately equal to $\$ 70,000$. According to him, data shows that Nigeria's GDP per capita is 50 times lesser than the average annual income of the Nigerian lawmakers. He noted that the lawmakers used to be the highest paid lawmakers in the world, by earning about $\$ 189.5$ thousand annually, a figure he considers higher than their American counterparts. He posits that in 2013, the salary of the US legislators exceeded American Gross Domestic Product GDP per capita less than four times, while Nigeria's lawmakers pay exceeded Nigerian GDP per capita 116 times. According to Professor Itse Sagay, the Nigerian lawmakers at the lower and upper chambers of the National Assembly are the highest paid legislators in the world. He noted that a Senator in Nigeria earns 240 million naira (about 1.7 million US dollars) in salaries and allowances and a member of the House of Representatives earns 204 million naira (about 1.45 million US dollars) per annum. This situation definitely rubs salt to injury for the average civil servant who earns about 46 to 120 US dollars per month (Animasaun, 2018).

\section{Neglect of their Oversight Functions}

Prebendalists in the National assembly are notorious for their role in neglecting their oversight functions. On numerous occasions, they have failed to appropriately monitor their oversight functions which serve as an instrument to promote budget implementation and execution. These elements see this as an opportunity to enrich themselves by adopting any report presented to them by the Ministers/Director Generals as far as their 'stomachs are taken care of'. These lawmakers shirk their responsibilities thereby laying a foundation for corruption to thrive (Abubakar, 2011). These oversight reports which serve as a viable instrument in the approval of budget estimates have continued to be compromised and as such the legislature appropriates fund for projects which its' allocation for the previous year was neither utilized nor accounted for. These prompted David Mark to reveal that the outcome of recent probes and investigation panels of the National Assembly show that the law makers see their oversight functions as opportunities for enriching themselves ("The legislature and oversight functions," 2012).

Just recently, there was controversy over a planned foreign trip for eight members of the National Assembly sponsored by the Nigeria Bulk Electricity Trading Plc (NBET). Anti - corruption crusaders were of the view that it was unacceptable for Nigerian lawmakers to be sponsored on local and foreign trips by government agencies they are supposed to have oversight on. It was reported that in November, 2017, NBET budgeted $\$ 96,350$ for the eight law makers to attend the $43^{\text {rd }}$ International Training Programme on Utility Regulation and Strategy; but cancelled the trip for undisclosed reasons. However, despite the cancellation, sources within NBET informed that the fund was approved and the money released to the law makers (Busari, 2018a). An internal memo of NBET obtained by Premium Times indicated that eight lawmakers, four each from the Senate and House of Representatives committees on power; clerks of the two committees; the Deputy 
INTERNATIONAL JOURNAL OF ACADEMIC RESEARCH IN BUSINESS AND SOCIAL SCIENCES Vol. 8, No. 7, July 2018, E-ISSN: 2222-6990 @ 2018 HRMARS

General Manager of NBET, Eugene Edeoga; and the Managing Director, Marilyn Amobi were drafted to attend the training (Busari, 2018a). The Senators are Enyinnaya Abaribe, Adamu Aliero, Olanrewaju Tejuosho and Mao Ohabunwa while the members of the House of Representatives are Daniel Asuquo, Mohammed Garba Gololo, Abdulmalik Zubairu and Iboro Ekanem. The clerks of the two committees are Gideon Zemo for the Senate and Sidi Ibrahim for the House of Representatives. Busari (2018a) note that out of the approved sum, $\$ 950$ was earmarked as estacode for each Senator per day. This means that by the end of the training, each Senator would be entitled to $\$ 9,500$ for 10 days. This was indicated as per diem on the memo. For members of the House of Representatives, $\$ 900$ was approved as estacode. Each of them would have received $\$ 9,000$, also indicated as per diem, for 10 days. A total of $\$ 4250$ at $\$ 425$ per day was approved as per diem for the two clerks and the DGM respectively while the MD was drafted to receive $\$ 9,600$ as per diem. The memo noted that the course fee, which includes payment for accommodation, had been paid for the eight lawmakers, their clerks and the Deputy General Manager (DGM) who would serve as accompanying staff of NBET on the trip.

Aside the issue of whether the estacodes were released to the supposed beneficiaries due to the cancellation, Busari (2018a) submits that the Senators and House of Representative members would have received more than they were constitutionally allowed if they had embark on the journey. The Revenue Mobilisation Allocation and Fiscal Commission RMAFC document shows that each Senator is allowed an entitlement of $\$ 600$ as estacode per day and $\$ 550$ for House of Representative member. From this, each of the lawmakers had $\$ 350$ extra budgeted for them per day. In sum, each of them had $\$ 3,500$ illegally approved for the training (Busari, 2018a)

\section{Delays in Budget Approval}

From the analysis of the Federal Budgeting process in Nigeria between 2000 and 2012 by the Nigerian Economic Summit Group NESG, it takes about 4 months on the average to complete a budget process in Nigeria from 'submission' to 'assent'. Data from the National Bureau of Statistics shows that the first quarter of every year since 2008 is characterized by slow GDP growth rates (NESG, 2013). Judging by the time at which the budgets were signed into law - which is usually in April, it means that delayed budget process negates economic growth (NESG, 2013). These delays cause low budget performance, a situation that can be explained in terms of the Federal Government's performance on the 2012 budget. NESG (2013) is of the view that the government only achieved $52.03 \%$ when actual spending is compared as a percentage of the total capital spending plan. Such low performance is attributable to a delayed budget which narrows down the one year implementation time frame.

Government rating of $92.80 \%$ implementation of the 2012 budget is based on measures of money spent instead of what the money was able to achieve. These low performances in budget and slow growth in the first quarter of every year which was as a result of delayed approval of budget is caused by the prebendalists in the legislature who normally demand money from ministries, agencies and parastatals before the budget is approved (Mamza, 2005). Collaborating this view, David Mark, a former Senate President agreed that the chairman and members of various committees have been exposed in some of these reports as having compromised their oaths by collecting bribes from the very government agencies in which they are supposed to oversee ("The legislature and oversight functions," 2012). The inability of these Agencies according to Mamza (2005) to meet up with the demands of these lawmakers might have been the cause of the delays in our yearly budget which appears to have defiled all possible measures adopted to ameliorate it. 
Aside these, Honourable Haruna Yerima have earlier accused his colleagues in the National Assembly of demanding for bribes from ministries in order to pass their budgets (Mamza, 2005). Legislatures who are members of the opposition party as well as friends of 'enemies of government' play a remarkable role in the delay of budget in order to frustrate the government and cause it not to deliver on its electoral promises. This can be deduced from the words of the then President, Goodluck Jonathan, that the divisions in the National Assembly could groom a fertile ground for antigovernment forces outside the government to use members of the parliament to frustrate the passage of the budget thereby leading to poor implementation (President, Speaker clash over separation of powers, budget," 2013).

\section{Theoretical Framework Prebendalism}

Richard Joseph's theory of Prebendalism is the most suitable for this paper.

A prebend is the right of member of chapter to his share in the revenues of a cathedral ("Prebend," 1911). Joseph adopted the term to describe the sense of entitlement that many people in Nigeria feel they have to the revenues of the Nigerian state. He posits that elected officials, government workers, and members of the ethnic and religious groups to which they belong feel they have a right to a share of government revenues (Joseph, 2013; Mustapha, 2010). Joseph (1987) further defines it as:

a system that is seen not only as one in which the offices of the state are allocated and then exploited as benefits by the office-holders but also as one in which such practice is legitimated by a set of political norms according to which the appropriation of such offices is not just an act of individual greed or ambition but concurrently the satisfaction of the shortterm objectives of a subset of the general population.

The theory explains how the primordial public network works to sabotage the working of an ideal Weberian bureaucracy in the civic public thereby rendering the Nigerian political structure a site of mere struggle for power and "sharing rights" (Oni, 2017). In fact, the term includes in the Nigerian context, a serious abuse of public office, for example, unauthorised retirement of funds in the budget, deliberate over-padding of expenditure votes, fraudulent encashment of cheques, charging of private expenditure to the public treasury, outright refusal to answer audit queries on discrepancies in the record of public finances, non-remittance of funds collected on behalf of the government, over-invoicing of government purchases, diversion of funds from approved projects and contracts, cronyism, etc. (Oni, 2017).

The system entails extreme personalization of political power in government, the consequent widespread use of state resources for patronage and clientelistic practices, and systematic political corruption, all of which "coexist with, and suffuse" the rational-legal institutons bequeathed to these countries by Western colonialism (Bratton and Walle, 1997). Like neopatrimonial systems elsewhere in Africa, prebendalism in Nigeria has involved the systematic use of official state resources (budgets, appointments, licenses, permits, etc.) for the private benefits of the office holders and their political or communal clienteles (Suberu, 2013). Joseph contends that the politics of competition over allocation of resources, or 'the national cake' as it is known in Nigeria, has its most dire consequences, which is the transformation of state's offices into prebend (Ogundiya, 2009).

Joseph started formulating the theory between 1976-1976 as a then lecturer of Political Science 
INTERNATIONAL JOURNAL OF ACADEMIC RESEARCH IN BUSINESS AND SOCIAL SCIENCES Vol. 8, No. 7, July 2018, E-ISSN: 2222-6990 @ 2018 HRMARS

at the University of Ibadan and completed it as a member of the Department of Government of Dartmouth College. The term first appeared in his book Democracy and Prebendal Politics. The term was used to describe the spoilt system as obtainable in Nigeria's Second Republic (Joseph, 2013). Since then the term has commonly been used in scholarly literatures and textbooks. Richard A. Joseph is now a Director of the Program of African Studies at Northwestern University, Illinois, United States of America.

The theory can be used to describe the activities of Nigerian lawmakers who jostle for positions only for them to go there to represent their 'pockets' at the detriment of the Nigerian masses. These lawmakers demand bribe from ministries before budget is approved, as well as engages in all types of unethical practices during the process of budget authorization.

\section{Conduit Pipes through which Lawmakers Prebendalize during Budget Authorization}

Reports show that the major conduit pipes through which the Nigerian lawmakers prebendalize include: enjoyment of illegal salaries and allowances, award/implementation of zonal constituency projects, and budget padding through agencies like Small and Medium Enterprises Development Agency of Nigeria (SMEDAN), Nigeria Directorate of Employment (NDE), Ogun-Osun River Basin Development Agency (OORBDA), Lower Niger River Basin Development Agency (LNRBDA) and other river basin agencies.

Despite the published details of official remunerations of all political office holders including members of the National Assembly by the Revenue Allocation and Fiscal Commission, controversy has continued to trail the amount received by the National Assembly members as their legitimate entitlements. In some instances, outrageous amounts of about one hundred million naira are said to be the quarterly constituency allowances of the Senators. This is apart from the monthly salary of more than a million naira which each Senator earns at the end of every month.

The secrecy with which issues of the real remuneration of legislators have been shrouded have all combined to present members of the legislature as the real problems of the economic difficulties of the country, prompting members of the public to see the National Assembly members as the real enemy of the Nigerian masses. These allegations were confirmed by the Governor of the Central Bank, Mallam Sanusi Lamido in a lecture delivered at the University of Benin, where he posits that $25 \%$ of the country's revenue spending goes to the national assembly on a yearly basis, a situation he described as being unhealthy for the country and its economy (Ajani, Agande \& Binniyat, 2010). He put it thus:

If you look at the budget, the bulk of the government revenue expenditure is on overhead; that is a big problem, $25 \%$ of the overhead of the Federal government goes to the National Assembly. We need power, we need infrastructure so we need to start looking at the structure of expenditure and make it more consistent with development initiative of the country.

The mathematics of $25 \%$ is that out of Government overhead of N536, 268,49,280 (536.2 Billion Naira) in 2010, a total of N136,259,768,112(136.2 Billion Naira) goes to the National Assembly as overhead cost representing $25.1 \%$ of the Federal Government overhead. The overhead of National Assembly as a percentage of the Federal Government budget in 2009 was 19.87 and in 2008 it was 14.19 (Ajani, Agande \& Binniyat, 2010).

The legislatures have been known to be increasing budget estimates from the various ministries, agencies and parastatals, this is done in collaboration with the ministry that presents the estimate. They do this on condition that part of the budget fund if approved will find its way into their private 
INTERNATIONAL JOURNAL OF ACADEMIC RESEARCH IN BUSINESS AND SOCIAL SCIENCES

Vol. 8, No. 7, July 2018, E-ISSN: 2222-6990 @ 2018 HRMARS

pockets. This was confirmed by the Senate President, David Mark as reported in Daily Trust of July 5, 2012 "that law makers are known to have increased ministerial budget estimates in the understanding that the excess would be skimmed off and the cash equivalent delivered to them" ("The legislature and oversight functions," 2012).

In recent years, details of the Zonal Intervention Projects of the 469 Senators and members of the House of Representatives in the six geo-political zones have been kept secret because the lawmakers engage in self-enriching deals in the implementation of the projects. Thus constituents hardly know what should statutorily accrue to them. For many constituencies, there has never been transparency around which projects were budgeted for, the funds released, or the estimated completion time for them. Often times, constituents 'worship' their lawmakers whenever a project is completed with the belief that they used their personal funds in executing the projects. In reality however, this is not the case. According to Busari (2018b), even though the projects are advertised in line with the Public Procurement Act, only contractors nominated by the lawmakers are often awarded the contracts. This situation allows some of the lawmakers to nominate companies in which they have interests in. In some cases, contractors that are awarded jobs only move the cash to lawmakers who nominated them and the contracts are not implemented in some instances.

Despite the fact that the lawmakers are not allowed direct access to the fund, they have devised several means of getting a cut from the zonal intervention project fund every year. One of such dubious means is by padding the budgets of government agencies. Analyses of the capital expenditure of some relevant government agencies, which carry out zonal intervention projects, show this trend. Agencies that serve as easy conduit pipe for them include the Small and Medium Enterprises Development Agency of Nigeria (SMEDAN), Nigeria Directorate of Employment (NDE), Ogun-Osun River Basin Development Agency (OORBDA), Lower Niger River Basin Development Agency (LNRBDA) and other river basin agencies. Busari (2018b) posit that an examination of the capital expenditure of Small and Medium Enterprises Development Agency of Nigeria (SMEDAN) between 2013 and 2017 shows an increasing trend of budgetary allocation. The document shows that in 2013, SMEDAN had a budget of N960 million but this increased to triple, at N2.7 billion the following year. The budgetary allocation stood at N778 million in 2015 and N1.8 billion in 2016. Worthy of note is the agency's budget of 2017. While SMEDAN proposed N2.18 billion for capital projects this year, the lawmakers increased it to N9.52 billion, which is more than the budget of the last six years. The reasons for these according to Busari (2018b) are that the lawmakers lodged most of their zonal intervention projects in the budget of the agency and secondly, it was made possible due to the nature of SMEDAN's mandate of promoting and facilitating developmental programmes, and support services to accelerate the development and modernization of Micro, Small \& Medium Enterprises MSME operations, especially in rural areas where it carries out projects like trainings, sensitisation, youth and women empowerment, supply of materials e.t.c. The non-quantitative nature of some of these projects make them difficult to measure or track, thereby creating a fertile corruption ground for the lawmakers. The lawmakers also lodge some of their projects in the budget of the Nigeria Directorate of Employment (NDE), Ogun-Osun River Basin Development Agency (OORBDA), Lower Niger River Basin Development Agency (LNRBDA) and other river basin agencies.

The NDE had a budget of N1.1 billion in 2013, N884 million in 2014, N175 million in 2015, and N1.9 billion in 2016. The budget sky-rocketed to N4 billion in 2017. Only recently, a civil society group, Socio-Economic Rights and Accountability Project (SERAP) asked Nigerian lawmakers to voluntarily 
return the money paid to them outside the law guiding the salaries and allowances of public officers in the country. The group urged the Senate President, Bukola Saraki, and Speaker of the House of Representatives, Yakubu Dogara, to persuade their members to voluntarily return running costs and other allowances which they have collected so far, and which has now been declared as illegal by the Revenue Mobilisation Allocation and Fiscal Commission (RMAFC). The group reasoned that the fund if returned could be used to establish a trust fund which could improve investment in education and health sector. This call became necessary after RMAFC disclosed that it did not provide for the payment of running cost to the lawmakers, which has been revealed as N13.5 million monthly for each Senator and N10million for each member of the House of Representatives (“Group asks Nigerians." 2018).

\section{Conclusions and Recommendations}

Budget authorization is a strong instrument through which the people have their say in the approval and implementation of government policies as well as the allocation of resources. However, this instrument has been misused over a long period of time by the legislatures who use it to 'help themselves' by making illegal demands from the ministries and parastatals, overbloat the budget as well as uses it to witch-hunt the executive. We now understand better why the Nigerian lawmakers fight tooth and nail to remain in the hallowed chamber.

In view of these, the paper recommends among others, that the House of Senate be scrapped in order to save cost, leaving only the House of Representatives which better represents the various diversities of Nigerians; the masses should stage a peaceful protest at the National Assembly Complex to demand for an end to the allocation of fat salaries and the increasing of budget estimates from the ministries and agencies; A true Sovereign National Conference should be convoked to determine the guidelines for effective leadership selection process, as our current crop of lawmakers appears not to be ready to zero their interest during a review of the Electoral Act. This will make way for people of character into the National Assembly.

\section{References}

Abubakar, A. (2011). Needed: A senate to perform oversight functions diligently. Daily Trust. Retrieved from https://www.dailytrust.com.ng/news/politics/needed-a-senate-to-performoversight-functions-diligently/91031.html

Agbajileke, O. (2017). Key events that shook Nigeria in 2016. Business Day. Retrieved from http://www.businessdayonline.com/key-eventsshook-nigeria-2016/

Ajani, J., Agande, B., and Binniyat, L. (2010). National assembly overhead: When figures don't lie. Vanguard. Retrieved from http://www.vanguaardngr.com/2010/12/national-assembly-overhead-when-figuresdon't- lie/.

Animasaun, D. (2013). Nigerian lawmakers are the highest paid in the world. Vanguard. Retrieved from https://www.vanguardngr.com/2013/08/nigerian-lawmakers-are-the-highest-paid-inthe-world/

Animasaun, D. (2018). Nigerian lawmakers' greed. Retrieved from https://www.vanguardngr.com/2018/03/nigerian-lawmakersgreed/

Bratton, M., and Van De Walle, N. (1997). Democratic experiments in Africa: Regime transitions in comparative perspective. New York: Cambridge University Press.

Busari, K. (2018) Analysis: How Nigerian lawmakers share N100 billion 
INTERNATIONAL JOURNAL OF ACADEMIC RESEARCH IN BUSINESS AND SOCIAL SCIENCES

Vol. 8, No. 7, July 2018, E-ISSN: 2222-6990 @ 2018 HRMARS

zonal intervention fund annually. Premium Times. Retrieved from

https://www.premiumtimesng.com/news/headlines/265828-analysis-how-nigerian-

lawmakers-share-n100-billion-zonal-intervention-fund-annually.html

Busari, K. (2018). Eight Nigerian lawmakers in $\$ 96,000$ foreign training

scandal. Premium Times. Retrieved from

https://www.premiumtimesng.com/news/headlines/264134-eight-nigerian-lawmakers-in96000-foreign-training-scandal.html.

Chikeleze, O. (2002). Principles and practice of budgeting: With public sector perspective. Enugu: Institute for Development Studies, University of Nigeria.

Group asks Nigerian lawmakers to return illegal allowances. (2018). Premium Times. Retrieved from https://www.premiumtimesng.com/news/more-news/263451-group-asks-nigerianlawmakers-to-return-illegal-allowances.html

Itaghene, E. (2018). What Nigeria can do with the billions pocketed by lawmakers as 'runningcost'. Ripples Nigeria. Retrieved from https://www.ripplesnigeria.com/nigeriacan-billions-pocketed-lawmakers-running-cost/

Joseph, R. (1987). Democracy and prebendal politics in Nigeria: The rise and fall of the Second Republic. Cambridge: Cambridge University Press

Joseph, R. (1996). Nigeria: Inside the dismal tunnel. Current History, 95: 193-200

Joseph, R. (2013). Prebendalism and dysfunctionality in Nigeria. Africa Plus. Retrieved from https://africaplus.wordpress.com/2013/07/26/prebendalism-and-dysfunctionality-innigeria/

Kazeem, Y. (2015). A dogged transparency campaign reveals why it pays to be a lawmaker in Nigeria. Quartz Africa. Retrievedfrom https://qz.com/983331/a-dogged-transparency-campaignreveals-why-it-pays-to-be-a-lawmaker-in-nigeria/

Mamza, P. (2005). OBJ on corruption: A thumb up but.... Retrieved from http://www.gamji.com/mamza/mamza61.htm

Mustapha, M. (2010). Corruption in Nigeria: Conceptual \& empirical notes. Information Society and Justice, 3(2):165-175.

Nwabueze, P. B. (1999). Budget preparation, monitoring and appraisal. A paper presented to Enugu State legislators on $21^{\text {st }}-23^{\text {rd }}$ June.

Nwagwu, E. J. (2017). Legislative Oversight in Nigeria: A Watchdog or a Hunting Dog? Journal of Law, Policy and Globalization, 22

Ogundiya, I. S. (2009). Political corruption in Nigeria: Theoretical perspectives and some explanations. Anthropologist, 11(4): 281-292

Oni, E. (2017). Governance and prebendalism in Nigeria: The past, the present and the future. International Journal of Social Science and Humanities Research, 5 (4): 424-436

Organisation for Economic Co-Operation and Development, OECD. (2002). Best practices for budget transparency. OECD Journal on Budgeting, 1(3): 7-14

Osagie, S. (2017). National assembly oversight functions: Constitutional provisions and implications for national development. Order Paper. Retrieved from https://www.orderpaper.ng/national-assembly-oversight-functions-constitutionalprovisions-implications-national-development/

Prebend. (1911). In the Catholic Encyclopedia. New York: Robert Appleton Company. Retrieved http://www.newadvent.org/cathen/12371a.htm 
INTERNATIONAL JOURNAL OF ACADEMIC RESEARCH IN BUSINESS AND SOCIAL SCIENCES

Vol. 8, No. 7, July 2018, E-ISSN: 2222-6990 @ 2018 HRMARS

President, Speaker clash over separation of powers, budget. (2013). Punch Newspaper. : 3.

Suberu, R. T. (2013). Prebendal politics and federal governance in Nigeria. In W. Adebanwi \& E. Obadare (Eds.), Democracy and Prebendalism in Nigeria: Critical Interpretations. New York: Palgrave Macmillan

Temionu, T. (2016). Budget padding and Nigeria's economy. The Punch. Retrieved from http://punchng.com/budget-padding-nigerias-economy/

The legislature and oversight functions. (2012). Daily Trust. Retrieved from http://www.dailytrust.com.ng/index.php/editorial/42372- the-legislature- andoversight- function

The Nigeria Economic Summit Group. (2011). Troubleshooting Nigeria's budgetary process. Retrieved from www.nesgroup.org 